\title{
Health CaRe Reform and the LAW IN CANADA: MeETING the Challenge, Timothy A. Caulfield \& Barbara von Tigerstrom, eds. (EDMONTON: UNIVERSITY OF AlberTA Press, 2002)
}

Review of the health care system with a view to reform has become a mounting political preoccupation in Canada. The Romanow Commission is only one of several concurrent and recent earlier commissions that have been constituted to address such key issues as appropriateness and adequacy of health services, equitable access and cost containment. Developments in medical technology and understanding, not least in the field of human genetics, trigger new promises and concerns to which the health care system is required to respond. Although the mortality rate among human populations is anticipated to remain at 100 percent, people's hopes to live better and longer impose continuing demands.

We have not answered the question, posed by Daniel Callahan, "Of what conditions is it acceptable to die?" We identify leading precipitating causes of death as diseases that resources must be applied against to conquer, without appreciating that the defeat of one cause, such as pneumonia, or, perhaps in time, cancer, will lead to the ascendancy and demonization of another primary cause of death. A focus on causes of premature death, such as HIV/AIDS and violence is, however, appropriate. Such a focus may permit us to accept that longevity will lead to a rise in primacy of age-related disorders, such as Alzheimer's and Parkinson's diseases, whose incidence and effects we will want health care services to reduce and relieve.

This book presents seven studies that set in context important parts of the legal framework within which we may respond to the challenge of reforming Canadian health care to address present and foreseeable concerns. The opening chapter, "Malpractice in the Age of Health Care Reform," by Timothy Caulfield, considers how the pressures of cost constraint may affect standards of care. ${ }^{2} \mathrm{He}$ discusses whether courts will accept that standards lowered due to the need for economy can nevertheless be legally satisfactory. The dilemma of physicians' double-agency is addressed, when duties they owe their patients conflict with their gate-keeping role to enforce public cost containment policies. Malpractice law requires a physician's primary and even exclusive allegiance to a patient, both to employ available but scarce resources for which other patients, even of the same physician, are competitors, and to disclose privately-funded options, perhaps offered for commercial profit contrary to principles of the Canada Health Act. $^{3}$

Viewing enforcement of the $C H A$ through the lens of federalism is the theme of Sujit Choudhry's chapter, entitled "Bill 11, the Canada Health Act and the Social Union: The Hopes: Why America's Quest for Perfect Health Is a Recipe for Failure (New York: Simon \& Schuster, 1998). the Challenge (Edmonton: University of Alberta Press, 2002) 11 [hereinafter Health Care Reform]. 
Need for Institutions." Alberta's Bill 11 permits operation of private, for-profit clinics able to offer services covered by the provincial health insurance plan, including "enhanced" services available more quickly or of superior quality, on a fee-for-service basis." Presenting a detailed historical review of (non-)enforcement of the CHA, the author asks what would constitute an ideal system of federal enforcement, and what institutions could mediate the potential for federal-provincial conflict.

A comparable theme is pursued from the viewpoint of private law in Moe Litman's chapter, "Fiduciary Law and For-Profit and Not-For-Profit Health Care." Judicial approaches to conflict of interest, in both profit-driven and non-profit health care, are drawn upon to conclude that the former health service providers, in contrast to the latter, are fiduciaries. The key to conflict of interest is not simply selfish or disloyal conduct by those who induce vulnerable people to rely on their power of superior knowledge, but a reasonable apprehension or appearance of conflict. The author finds this in the provision of health services for private profit, and rigorously explains the supporting case law. In contrast, actors who seek economic practice in not-for-profit, public health care settings are not in a conflict of interest, but are "part of an unfortunate but necessary process of juggling resources so as to maximize patient benefit."

The title of Colleen Flood's chapter, "Moving Medicare Home: The Forces Shifting Care Out of Hospitals and Into Homes," is self-explanatory. ${ }^{8}$ She is sceptical that policy-makers' greater focus on "health," and reduced focus on access to health care services is enlightened or benign, and points to the burden homecare imposes, particularly on low-income families and women. She explains that a justifiable shift to homecare must include public funding for drugs and medical equipment, and that "serious consideration should be given to compensating individuals on low incomes for the time they spend in caregiving." ${ }^{9}$ Care delivered at home by loved ones has a warm, compassionate appeal, but caution is compelled by the experience of how earlier decades' rhetoric of community care for the mentally impaired has degenerated in many cases into community neglect.

Barbara von Tigerstrom shifts the book's focus from the domestic to the wider international and national arenas in her chapter on "Human Rights and Health Care Reform: A Canadian Perspective." 10 She opens by addressing the right to health and to health care services under international human rights law and the Canadian Charter of Rights and Freedoms. "The Charter gives national effect particularly to the

Health Care Reform, supra note 2, 37.

Bill 11. Health Care Protection Act. 4th Sess., 24th Leg., Alberta, 2000 (assented to 30 May 2000.

R.S.A. 2000, c. H-1).

Health Care Reform, supra note 2, 85.

Ibid. at 115.

lbid. at 131-56.

Ibid. at 149.

Ibid. at 157.

Canadian Charter of Rights and Freedoms, Part I of the Constitution ACt, 1982. being Schedule $\mathrm{B}$ to the Canada ACl 1982 (U.K.). 1982. c. 11 [hereinafter Charter]. 
International Covenant on Civil and Political Rights. ${ }^{12}$ The right to the highest attainable standard of physical and mental health is recognized in the companion International Covenant on Economic, Social and Cultural Rights, ${ }^{13}$ but in operation, international tribunals tend to treat human rights and the covenants that express them as intersecting and permeable. ${ }^{14}$ Through her review of recent judgments regarding health services, the author shows how recognition of health care rights has implications for the recognition of other rights, such as to legal and social welfare services.

In the chapter entitled "A New Direction in Mental Health Law: Brian's Law and the Problematic Implications of Community Treatment Orders," Is Peter Carver narrows his focus to Ontario's amendments of its Mental Health Act, ${ }^{16}$ to follow Saskatchewan's model that requires persons with serious mental illness who live in the community to comply with proposed psychiatric treatment. ${ }^{17}$ The coercive nature of management of psychiatric patients seems incongruous with the modern patients' rights ethos, but is supported, for instance, by groups representing family members of schizophrenic and similarly affected mental health patients. They and the wider community are affected by patients' noncompliance with treatment that contributes to institutional open-door policies, producing revolving-door results. To break the cycle of repeat hospitalizations, the concept has evolved of maintaining community residence, but on the condition of legally enforceable medical treatment. The author explains how this approach challenges, and is challenged by, s. 7 of the Charter, which protects liberty and security of the person (subject, of course, to s. 1 limitations).

The concluding substantive chapter again changes focus. Richard Gold considers "Health Care Reform and International Trade,"18 with special regard to the North American Free Trade Agreement and World Trade Organization agreements. ${ }^{19}$ NAFTA and the WTO agreement cover health care services, but in sufficiently general and vague terms as to leave considerable uncertainty about their consequences. The author addresses obligations, exemptions and reservations under both schemes, pointing out that, despite uncertainties, there are two clear effects. The first is that, if a province opens health care to private enterprise, "that opening is irreversible without the payment

International Covenant on Civil and Political Rights, 19 December 1966, 999 U.N.T.S. 171, Can. T.S. 1976 No. 47, 6 I.L.M. 368 (entered into force 23 March 1976, accession by Canada 19 May 1976).

International Covenant on Economic, Social and Cultural Rights, 19 December 1966, 993 U.N.T.S. 3, Can. T.S. 1976 No. 46 at Art. 12(I). Fusion of the International Covenant on Human Rights" (1989) 27 Osgoode Hall L.J. 769. Health Care Reform, supra note 2, 187. Mental Health Act, R.S.O. 1990, c. M-7, as am. by An Act, in Memory of Brian Smith, to Amend the Mental Health Act and the Health Care Consent Act. 1996, S.O. 2000, c. 9.

17 See Mental Health Services Act, S.S. 1984-85-86, c. M-13.1, as am.

is Health Care Reform, supra note 2, 223.

19 North American Free Trade Agreement Between the Government of Canada. The Government of Mexico and the Government of the United States, 17 December 1992, Can. T.S. 1994 No. 2, 32 I.L.M. 289 (entered into force 1 January 1994) [hereinafter NAFTA]; Agreement Establishing the World Trade Organization, 15 April 1994, 33 I.L.M. 1144 [hereinafter WTO Agreement]. 
of substantial compensation." 20 Second, "Canada must abide by strict rules with respect to intellectual property protection over medical devices and pharmaceuticals." 21 The conclusion is that experiments in health care reform should be thought through very carefully in advance.

Brent Windwick's Afterword addresses future challenges, noting that cost constraints in health care services are here to stay, legal processes will be under stress, medical advances are as likely to increase as to decrease economic pressures, physicians will continue to drive resource allocation concerns, and health policy-makers and lawmakers will have to transcend purely local considerations. ${ }^{22}$ He presents a perceptive distillation of this somewhat eclectic but valuable and timely collection of modern studies. Following the Afterword is a useful 38-page "Health Care Reform Project Bibliography," consisting of post-1985 published materials related to the different chapters. $^{23}$

This book may in due course be outdated by evolving developments, but it offers helpful illumination on how Canadian law may accommodate, be affected by, and challenge options for health care reform. It lacks an index by which researchers can quickly locate discussions of particular topics, but their time spent exploring its chapters and the full set of references that supports each of them will not be wasted.

Bernard M. Dickens

Dr. William M. Scholl Professor of Health Law and Policy

University of Toronto

21) Health Care Reform, supra note 2 at 241.

$=\quad$ Ibid. at 241-42.

$\therefore \quad$ lbid. at 245 .

:3 Ibid. at 251 . 